\title{
STRUCTURE, MICROSTRUCTURE, AND PIEZOELECTRIC PROPERTIES OF KNLNS-BNKZ LEAD-FREE CERAMICS UNDER THE EFFECT OF DIFFERENT SINTERING TEMPERATURES
}

\author{
Phan Dinh Gio ${ }^{a *}$, Huynh Thi Chi ${ }^{b}$, Le Tran Uyen Tu ${ }^{a}$, Nguyen Truong Tho ${ }^{a}$
}

${ }^{a}$ The Faculty of Electronics-Electrical Engineering-Material Technology, University of Sciences, Hue University, Thua Thien Hue, Vietnam

${ }^{b}$ The Faculty of Physics, Quy Nhon University, Binh Dinh, Vietnam

${ }^{*}$ Corresponding author: Email: pdg_55@yahoo.com

\author{
Article history \\ Received: March $6^{\text {th }}, 2021$ \\ Received in revised form ( $\left.1^{\text {st }}\right)$ : May $29^{\text {th }}, 2021 \mid$ Received in revised form $\left(2^{\text {nd }}\right)$ : June $18^{\text {th }}, 2021$
}

Accepted: June $22^{\text {nd }}, 2021$

Available online: July $22^{\text {nd }}, 2021$

\begin{abstract}
Samples of $0.96\left(\mathrm{~K}_{0.48} \mathrm{Na}_{0.48} \mathrm{Li}_{0.04}\right)\left(\mathrm{Nb}_{0.95} \mathrm{Sb}_{0.05}\right) \mathrm{O}_{3}-0.04 \mathrm{Bi}_{0.5}\left(\mathrm{Na}_{0.82} \mathrm{~K}_{0.18}\right)_{0.5} \mathrm{ZrO}_{3}$ piezoelectric ceramic were fabricated with conventional ceramic techniques and sintered at different temperatures. The effect of sintering temperature $\left(T_{S}\right)$ on the structure, microstructure, and piezoelectric properties of the ceramics was studied in detail. The experimental results showed that with an increase of the $T_{S}$ temperature, the structure of the ceramics transformed from an orthorhombic-tetragonal mixed phase $(O-T)$ at $T_{S} \leq 1100^{\circ} \mathrm{C}$ into a rhombohedral-tetragonal $(R-T)$ mixed phase with a dense microstructure of uniform grain size at $T_{S}=1110^{\circ} \mathrm{C}$. When $T_{S}$ was further increased $\left(T_{S} \geq 1120^{\circ} \mathrm{C}\right)$, the ceramics showed only a rhombohedral phase $(R)$. The ceramics showed the best electrical properties for $T_{S}=1110^{\circ} \mathrm{C}$ at which the rhombohedral and tetragonal $(R-T)$ phases coexist. Specifically, the ceramic density reached its highest value $\left(4.22 \mathrm{~g} / \mathrm{cm}^{3}\right)$, the electromechanical coupling coefficients $k_{p}$ and $k_{t}$ were 0.46 and 0.50, respectively, and the piezoelectric coefficient $d_{33}$ was $245 \mathrm{pC} / \mathrm{N}$.
\end{abstract}

Keywords: KNLNS-BNKZ ceramics; Microstructure; Piezoelectric; Sintering temperature.

DOI: http://dx.doi.org/10.37569/DalatUniversity.11.4.862(2021)

Article type: (peer-reviewed) Full-length research article

Copyright $@ 2021$ The author(s).

Licensing: This article is licensed under a CC BY-NC 4.0 


\section{INTRODUCTION}

Piezoelectric ceramics are special functional materials that have been widely applied in many electronic devices. Since the 1950s, $\mathrm{PbZr}_{1-\mathrm{x}} \mathrm{Ti}_{\mathrm{x}} \mathrm{O}_{3}(\mathrm{PZT})$ ceramics have attracted much attention due to their excellent piezoelectric properties. As a result, PZTbased ceramics are widely used in most types of piezoelectric equipment (Haertling, 1999). However, more than $60 \%$ of the toxic lead elements in the PZT have greatly affected the surrounding environment during fabrication and processing. Therefore, many countries have focused on research and development of lead-free piezoelectric materials to replace lead-based piezoelectric materials (European Union, 2003).

Since Saito et al. (2004) reported a high $\mathrm{d}_{33}$ piezoelectric coefficient of $416 \mathrm{pC} / \mathrm{N}$ in textured KNN ceramics doped by $\mathrm{Li}$, Ta, and $\mathrm{Sb}$, KNN-based ceramics have become one of the widely studied lead-free piezoelectric materials (Phan \& Nguyen, 2015; Phan et al., 2018; Phan et al., 2021; Tan et al., 2018; Wang et al., 2014; Zhai et al., 2019; Zhang et al., 2020). The construction of a rhombohedral-tetragonal (R-T) polymorphic phase boundary was carried out to enhance the piezoelectric properties of this ceramic system (Tan et al., 2018; Wang et al., 2014; Xing et al., 2018). Because the domain walls rotate easily for the coexisting phases, the piezoelectric properties of the ceramics are significantly improved (Gao et al., 2014). On that basis, many recent studies have focused on studying the structural phase evolution of KNN-based ceramics by partially replacing A-site $\left(\mathrm{Na}^{+}, \mathrm{K}^{+}\right)$and $\mathrm{B}$-site $\left(\mathrm{Nb}^{5+}\right)$ ions with similar ions, such as $\mathrm{Li}^{+}, \mathrm{Sb}^{5+}, \mathrm{Ta}^{5+}$ in the $\mathrm{ABO}_{3}$-type (KNN) perovskite structure (Guo et al., 2004; Saito et al., 2004; Tangsritrakul \& Hall, 2018; Wang et al., 2014) or by adding other perovskite compounds into the KNN, such as $\mathrm{Bi}_{0.5}\left(\mathrm{Na}_{0.82} \mathrm{~K}_{0.18}\right)_{0.5} \mathrm{ZrO}_{3}$ (Tangsritrakul \& Hall, 2018) or $\mathrm{Bi}_{0.5}\left(\mathrm{Na}_{0.9} \mathrm{~K}_{0.1}\right)_{0.5} \mathrm{TiO}_{3}$ (Huang et al., 2014) to form a rhombohedral-tetragonal phase boundary at or near room temperature, similar to the morphotropic phase boundary in PZT, to enhance the piezoelectric coefficient $\mathrm{d}_{33}$ of $\mathrm{KNN}$-based ceramics $(\mathrm{Xu}, 1991)$.

In addition, the sintering process of KNN-based piezoelectric ceramics often encounters many difficulties due to the evaporation of alkaline elements at high sintering temperatures, leading to a nonstoichiometric composition for the ceramics and the appearance of a second phase. As is well-known, sintering is the most important step in the technological process of fabricating ceramic materials, and the sintering temperature plays a major role in affecting the quality of the ceramics. Therefore, controlling the sintering temperature during ceramic sintering is very important (Huang et al., 2014; Wu et al., 2014).

In this paper, we present some research results on the effect of sintering temperature on the structure, microstructure, and piezoelectric properties of $0.96\left(\mathrm{~K}_{0.48} \mathrm{Na}_{0.48} \mathrm{Li}_{0.04}\right)\left(\mathrm{Nb}_{0.95} \mathrm{Sb}_{0.05}\right) \mathrm{O}_{3}-0.04 \mathrm{Bi}_{0.5}\left(\mathrm{Na}_{0.82} \mathrm{~K}_{0.18}\right)_{0.5} \mathrm{ZrO}_{3}$ multi-component piezoelectric ceramics to identify the optimum sintering temperature corresponding to the best electrical properties for the ceramics. 


\section{EXPERIMENTAL PROCEDURE}

Ceramic material was prepared according to the chemical formula 0.96 $\left(\mathrm{K}_{0.48} \mathrm{Na}_{0.48} \mathrm{Li}_{0.04}\right)\left(\mathrm{Nb}_{0.95} \mathrm{Sb}_{0.05}\right) \mathrm{O}_{3}-0.04 \mathrm{Bi}_{0.5}\left(\mathrm{Na}_{0.82} \mathrm{~K}_{0.18}\right)_{0.5} \mathrm{ZrO}_{3} \quad$ (KNLNS-0.04BNKZ) from oxides and carbonates $\mathrm{Bi}_{2} \mathrm{O}_{3}, \mathrm{Sb}_{2} \mathrm{O}_{3}, \mathrm{ZrO}_{2}, \mathrm{Na}_{2} \mathrm{CO}_{3}, \mathrm{~K}_{2} \mathrm{CO}_{3}, \mathrm{Nb}_{2} \mathrm{O}_{5}$, and $\mathrm{Li}_{2} \mathrm{CO}_{3}$ with $99 \%$ purity using the conventional solid-state reaction method. Before the raw materials were weighed according to their stoichiometric formulas, the $\mathrm{K}_{2} \mathrm{CO}_{3}$ and $\mathrm{Na}_{2} \mathrm{CO}_{3}$ powders were dried in an oven at $150{ }^{\circ} \mathrm{C}$ for 2 hours to minimize the effect of moisture. The mixture was ball milled in ethanol for 10 hours, and then calcined at $850{ }^{\circ} \mathrm{C}$ for 2 hours in air to obtain a homogeneous composition. After that, the calcined powders were further ball milled for 16 hours, pressed into disks of $12.0 \mathrm{~mm}$ diameter and $1.5 \mathrm{~mm}$ thickness under a pressure of $1.5 \mathrm{~T} / \mathrm{cm}^{2}$, and sintered at temperatures of $1090{ }^{\circ} \mathrm{C}, 1100{ }^{\circ} \mathrm{C}$, $1110^{\circ} \mathrm{C}, 1120^{\circ} \mathrm{C}$, and $1130{ }^{\circ} \mathrm{C}$ for 2 hours in a Lenton furnace (UAF model, England).

The densities of the samples were measured by Archimedes' principle. The crystal phase structure and microstructure of the samples were examined at room temperature by X-ray diffraction (XRD; Bruker D8 ADVANCE) and scanning electron microscope (SEM; Hitachi S-4800). The ceramic samples were coated with silver paste on both sides to serve as electrodes to measure electrical properties. The samples were polarized in silicon oil at $60{ }^{\circ} \mathrm{C}$ with a dc field of $35 \mathrm{kV} / \mathrm{cm}$ for $20 \mathrm{~min}$ and then aged for 24 hours. The piezoelectric properties of the KNLNS-0.04BNKZ samples were determined using an impedance analyzer (HP 4193A and RLC Hioki 3532) to measure the radial and thickness resonant vibration spectra. The piezoelectric factor $\left(d_{33}\right)$ was determined by a $d_{33}$ meter (YE2730A, SINOCERA, China).

\section{RESULTS AND DISCUSSION}

\subsection{Phase structure of the KNLNS-0.04BNKZ ceramics at different sintering temperatures}

Figure 1a shows the XRD pattern in the $2 \theta$ range of $20-80^{\circ}$ measured at room temperature with $\mathrm{Cu}-\mathrm{K}_{\alpha}$ radiation of wavelength $1.5405 \AA$ for the KNLNS-0.04BNKZ ceramics sintered at temperatures of $1090{ }^{\circ} \mathrm{C}, 1100^{\circ} \mathrm{C}, 1110^{\circ} \mathrm{C}, 1120^{\circ} \mathrm{C}$, and $1130{ }^{\circ} \mathrm{C}$. It can be seen that the ceramic samples all exhibit a pure perovskite phase. No secondary phase was detected, indicating that BNKZ diffused into the KNN matrix to create a homogeneous KNLNS-0.04BNKZ solid solution regardless of sintering temperature. With the increase in sintering temperature, the characteristic shape of the diffraction peak for ceramic samples at $2 \theta \approx 45.5^{\circ}$ changed, showing that sintering temperature has a great influence on the crystal structure of KNLNS-0.04BNKZ ceramics.

To further investigate the effect of sintering temperature on the phase structure transition of KNLNS-0.04BNKZ ceramics, the XRD patterns of the ceramic samples at $2 \theta \approx 45.5^{\circ}$ were enlarged and simulated with Gaussian fitting functions (Figure $1 \mathrm{~b}$ ). As seen in Figure 1b, when the sintering temperature increases from $1090^{\circ} \mathrm{C}$ to $1110{ }^{\circ} \mathrm{C}$, the diffraction peaks at $2 \theta \approx 45.5^{\circ}$ broaden due to the overlap of multiple phases. For KNLNS-0.04BNKZ ceramic samples sintered at $T_{S} \leq 1100{ }^{\circ} \mathrm{C}$, the Gaussian function 
simulations confirm that the phase structure of the ceramic sample is a combination of orthorhombic and tetragonal (O-T) phases. At $T_{S}=1090{ }^{\circ} \mathrm{C}$, the double diffraction peaks $(220)_{\mathrm{O}}$ and $(020)_{\mathrm{O}}$ characteristic of the orthorhombic phase $(\mathrm{O})$ are dominant compared to the $(002)_{\mathrm{T}}$ and $(200)_{\mathrm{T}}$ peaks of the tetragonal (T) phase (Yao et al., 2014). In contrast, at $T_{S}=1100{ }^{\circ} \mathrm{C}$, the tetragonal phase is dominant. With $T_{S}=1110{ }^{\circ} \mathrm{C}$, the phase structure of the ceramic sample is a mixture of rhombohedral and tetragonal (R-T) phases characterized by the overlap of $(002)_{\mathrm{T}},(200)_{\mathrm{T}}$, and $(200)_{\mathrm{R}}$ diffraction peaks in which the intensity of the double peak $(002)_{\mathrm{T}}$ and $(200)_{\mathrm{T}}$ of the tetragonal $(\mathrm{T})$ phase is lower than that of the $(200)_{\mathrm{R}}$ peak of the rhombohedral $(\mathrm{R})$ phase. As $T_{S}$ further increases $\left(T_{S} \geq\right.$ $1120^{\circ} \mathrm{C}$ ), the characteristic diffraction peaks of the tetragonal phase disappear, and the ceramics only exist in a rhombohedral phase characterized by a single peak $(200)_{\mathrm{R}}$. Obviously, the change in sintering temperature has a strong influence on the structure of the ceramics. The effect may be related to the extent of the volatilization of alkali metal ions during sintering at different temperatures (Cheng et al., 2014). These results are consistent with the research of Liang et al. (2011) and Cheng et al. (2014) on the effect of sintering temperature on the phase structure of the $0.98\left(\mathrm{~K}_{0.5} \mathrm{Na}_{0.5}\right) \mathrm{NbO}_{3}$ 0.02 $\left(\mathrm{Ba}_{0.6} \mathrm{Sr}_{0.4}\right)_{0.7} \mathrm{Bi}_{0.3} \mathrm{TiO}_{3}$ and $\left(\mathrm{K}_{0.465} \mathrm{Na}_{0.465} \mathrm{Li}_{0.07}\right)\left(\mathrm{Nb}_{0.95} \mathrm{Sb}_{0.05}\right) \mathrm{O}_{3}$ ceramics. According to previous work (Qin et al., 2016; Rubio-Marcos et al., 2015; Tan et al., 2018; Tangsritrakul et al., 2020), ceramics will achieve excellent piezoelectric properties at or near the polymorphic phase boundary between rhombohedral and tetragonal (R-T) phases. In addition, the diffraction peaks shifted slightly to higher $2 \theta$ angles with increasing sintering temperature. This indicates that the unit cell volumes decreased when the sintering temperature increased, likely due to the alkaline elements ( $\mathrm{Na}$ and $\mathrm{K}$ ) being easily volatilized at high temperatures and creating more vacancies at A-sites of the lattice, which eventually results in shrinkage of the unit cells (Palei \& Kumar, 2012; Su et al., 2018).

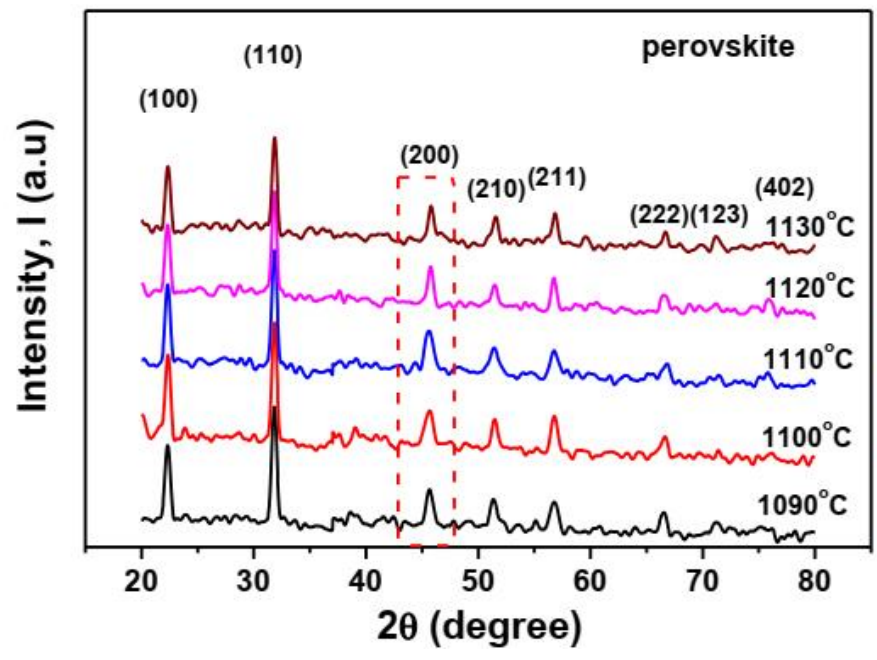

(a)

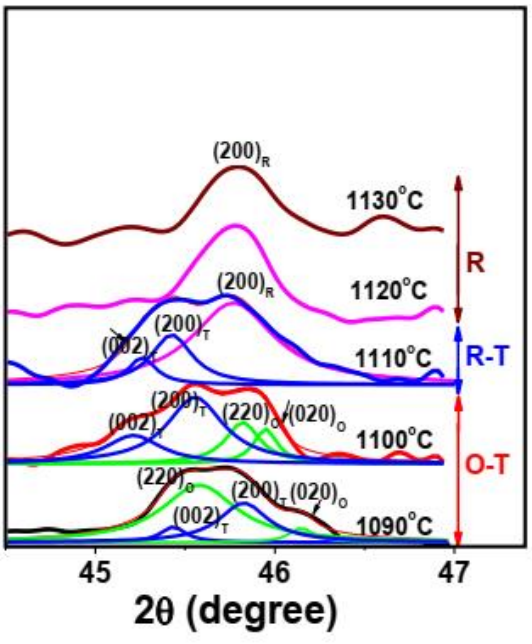

(b)

Figure 1. (a) XRD patterns of the KNLNS-0.04BNKZ ceramics sintered at temperatures of $1090{ }^{\circ} \mathrm{C}, 1100{ }^{\circ} \mathrm{C}, 1110{ }^{\circ} \mathrm{C}, 1120{ }^{\circ} \mathrm{C}$, and $1130{ }^{\circ} \mathrm{C}$; (b) Expanded XRD patterns of the ceramic samples at $2 \theta \approx 45.5^{\circ}$ and simulations using Gaussian fitting functions 


\subsection{Density and microstructure of the KNLNS-0.04BNKZ ceramics at different sintering temperatures}

The density of the ceramic samples was determined by the Archimedes method using an electronic balance (OHAUS-Model PA214C) with an accuracy of $0.1 \mathrm{mg}$. The mass of the sample when weighed in air is $\mathrm{m}_{1}$, and $\mathrm{m}_{2}$ is the mass of the sample when totally submerged in ethanol. Thus, the $D$ density of the sample is calculated by:

$$
D=\frac{m_{1}}{m_{1}-m_{2}} D_{\text {Ethanol }}
$$

where $D_{\text {ethanol }}=0.791 \mathrm{~g} / \mathrm{cm}^{3}$ is the density of ethanol.

Based on Equation 1, the densities of the KNLNS-0.04BNKZ ceramic samples at different sintering temperatures were determined, as shown in Table 1.

Table 1. The density of KNLNS-0.04BNKZ ceramic samples at sintering temperatures of $1090^{\circ} \mathrm{C}, 1100{ }^{\circ} \mathrm{C}, 1110{ }^{\circ} \mathrm{C}, 1120^{\circ} \mathrm{C}$, and $1130{ }^{\circ} \mathrm{C}$

\begin{tabular}{lllll}
\hline$T_{S}\left({ }^{\circ} \mathrm{C}\right)$ & $\mathrm{m}_{1}(\mathrm{~g})$ & $\mathrm{m}_{2}(\mathrm{~g})$ & $\mathrm{m}_{1}-\mathrm{m}_{2}(\mathrm{~g})$ & Density, $D\left(\mathrm{~g} / \mathrm{cm}^{3}\right)$ \\
\hline 1090 & 0.3719 & 0.2969 & 0.0750 & $3.93 \pm 0.03$ \\
1100 & 0.1710 & 0.1381 & 0.0329 & $4.11 \pm 0.02$ \\
1110 & 0.3677 & 0.2990 & 0.0687 & $4.22 \pm 0.02$ \\
1120 & 0.2322 & 0.1876 & 0.0446 & $4.12 \pm 0.04$ \\
1130 & 0.2936 & 0.2357 & 0.0579 & $4.01 \pm 0.03$ \\
\hline
\end{tabular}

Figure 2 shows the sintering temperature dependence of the density and microstructure of the KNLNS-0.04BNKZ ceramics. It can be clearly seen that the sintering temperature strongly influenced the density and microstructure of the KNLNS$0.04 \mathrm{BNKZ}$ ceramics. Figure 2a shows that by increasing the $T_{S}$ temperature from $1090^{\circ} \mathrm{C}$ to $1130{ }^{\circ} \mathrm{C}$, the density of the ceramic increased to a maximum value of $4.22 \mathrm{~g} / \mathrm{cm}^{3}$ at $T_{S}=1110{ }^{\circ} \mathrm{C}$, then decreased. The density decrease at higher sintering temperatures may be attributable to the formation of many sodium and potassium vacancies (Su et al., 2018).

Figure $2 b-2 f$ shows SEM images of fracture surfaces of the KNLNS-0.04BNKZ ceramic samples sintered at the different temperatures. As can be seen, the average grain size of the ceramics increased significantly when the $T_{S}$ temperature increased. For the sample sintered at a low temperature of $1090{ }^{\circ} \mathrm{C}$ (Figure $2 \mathrm{~b}$ ), the ceramic has a porous microstructure with small grains of unclear shape $(\sim 0.2 \mu \mathrm{m})$ and agglomerate, which may be the reason for the low ceramic density $\left(3.93 \mathrm{~g} / \mathrm{cm}^{3}\right)$. However, with an increase in sintering temperature, the ceramic microstructure gradually improved and the average grain size increased, with relatively more uniform grains having rectangular or cubic shapes and markedly decreased porosity. Especially, at $T_{S}=1110^{\circ} \mathrm{C}$ (Figure 2d), the microstructure of the ceramic became denser with sharply shaped grains $(\sim \mu \mathrm{m})$ consistent with the high density $\left(4.22 \mathrm{~g} / \mathrm{cm}^{3}\right)$. With further increases in $T_{\mathrm{S}}$ temperature 
$\left(T_{S} \geq 1120^{\circ} \mathrm{C}\right)$ (Figure 2e-2f), the ceramic microstructure became porous and consisted of larger rectangular grains with an average grain size of about $1.5 \mu \mathrm{m}$ and many fine grains of unclear shape distributed at the boundaries of the coarse grains. Thus, it can be seen that the increase in sintering temperature promoted the growth of grains, indicating that increased thermal energy enhances atom diffusion at higher sintering temperatures (Xu, 1991; Palei \& Kumar, 2012; Su et al., 2018). These results are consistent with the measured ceramic densities and are similar to previous results (Huang et al., 2014; Su et al., 2018). Thus, from the above results, it can be concluded that the optimum sintering temperature of the KNLNS-0.04BNKZ ceramics is $1110^{\circ} \mathrm{C}$.

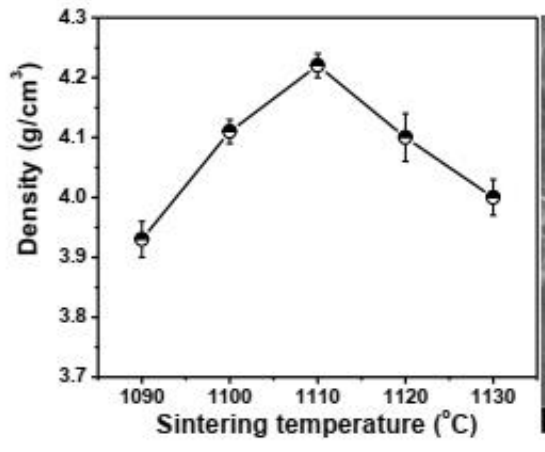

(a)

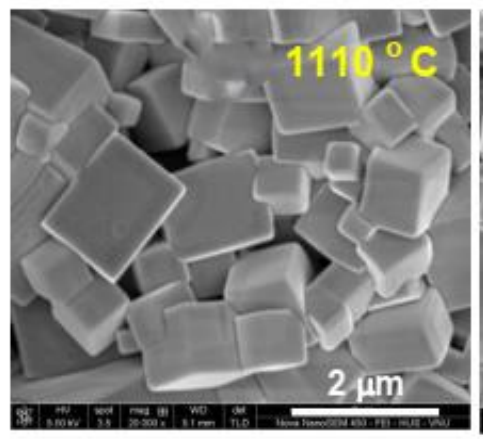

(d)

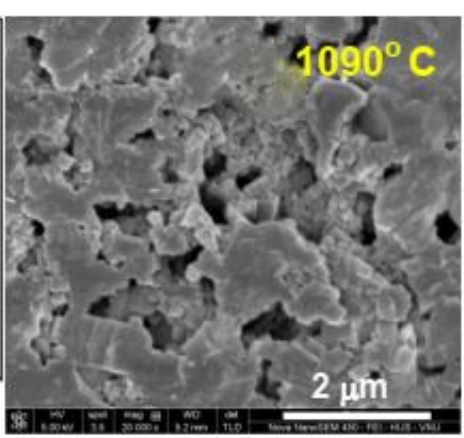

(b)

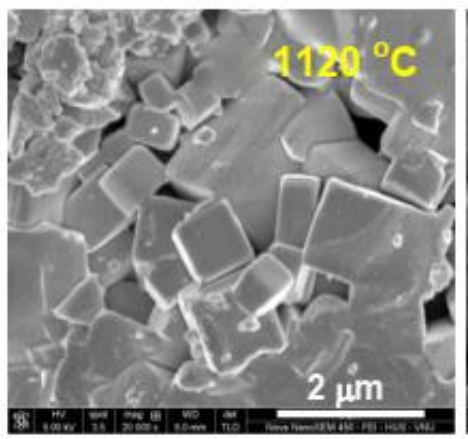

(e)

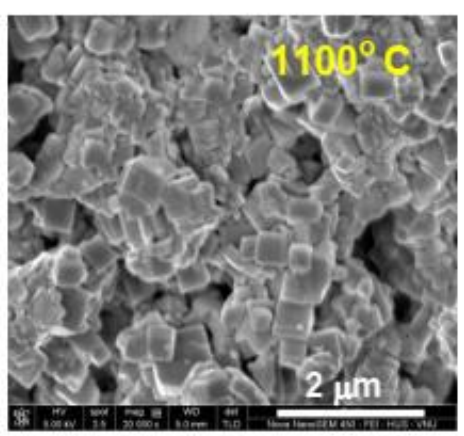

(c)

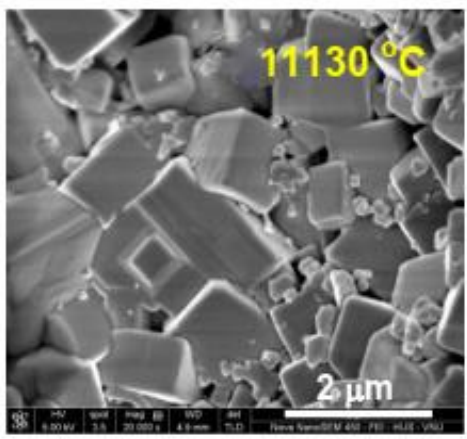

(f)

Figure 2. (a) Density and (b-f) SEM images of KNLNS-0.04BNKZ ceramics at sintering temperatures of $1090{ }^{\circ} \mathrm{C}, 1100{ }^{\circ} \mathrm{C}, 1110{ }^{\circ} \mathrm{C}, 1120{ }^{\circ} \mathrm{C}$, and $1130{ }^{\circ} \mathrm{C}$

\subsection{Piezoelectric properties of KNLNS-0.04BNKZ ceramics at different sintering temperatures}

To determine the dependence of the piezoelectric properties of the KNLNS0.04BNKZ ceramics on sintering temperature, the resonant vibration spectra of the ceramic samples sintered at different $T_{S}$ temperatures were measured at room temperature.

Figure 3 shows the radial and thickness resonant vibration spectra of the KNLNS0.04BNKZ ceramic sample sintered at $T_{S}=1110^{\circ} \mathrm{C}$, representing the frequency dependence of the impedance $Z$ and phase angle $\theta$. Based on these vibration spectra, we 
used the equations from the IRE-61 Standards (Jaffe et al., 1961) to calculate the electromechanical coupling coefficients, $k_{p}$ and $k_{t}$. The piezoelectric factor $\left(d_{33}\right)$ was determined by a $d_{33}$ meter.

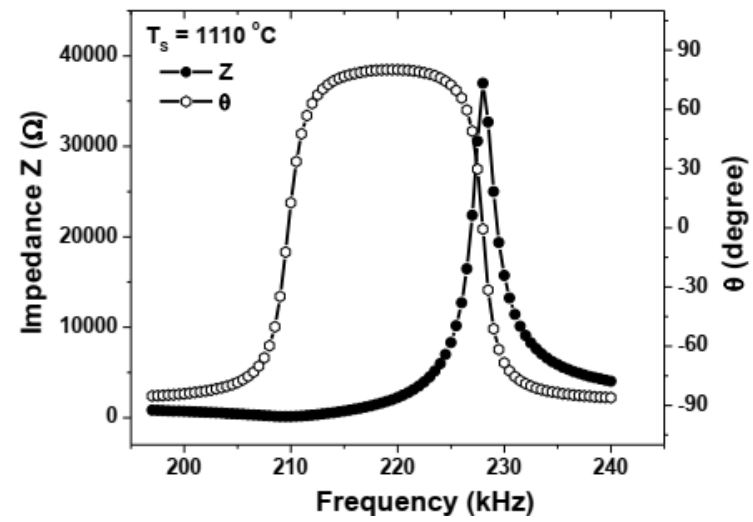

(a)

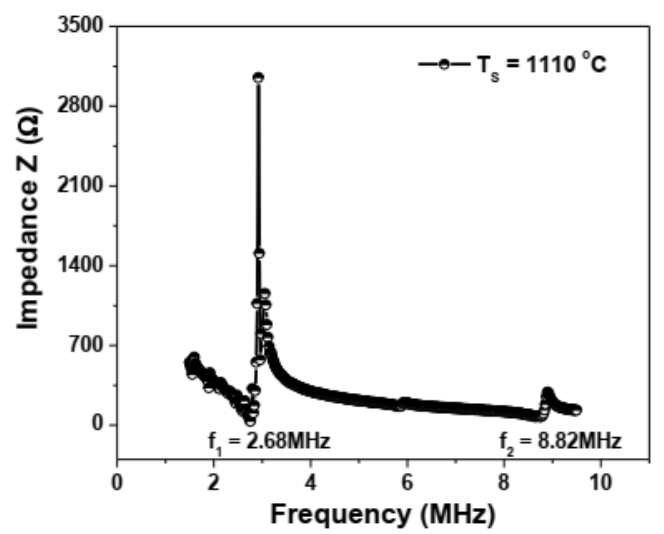

(b)

Figure 3. (a) Radial and (b) thickness resonant vibration spectra of the KNLNS0.04BNKZ ceramic sample sintered at $T_{S}=1110{ }^{\circ} \mathrm{C}$

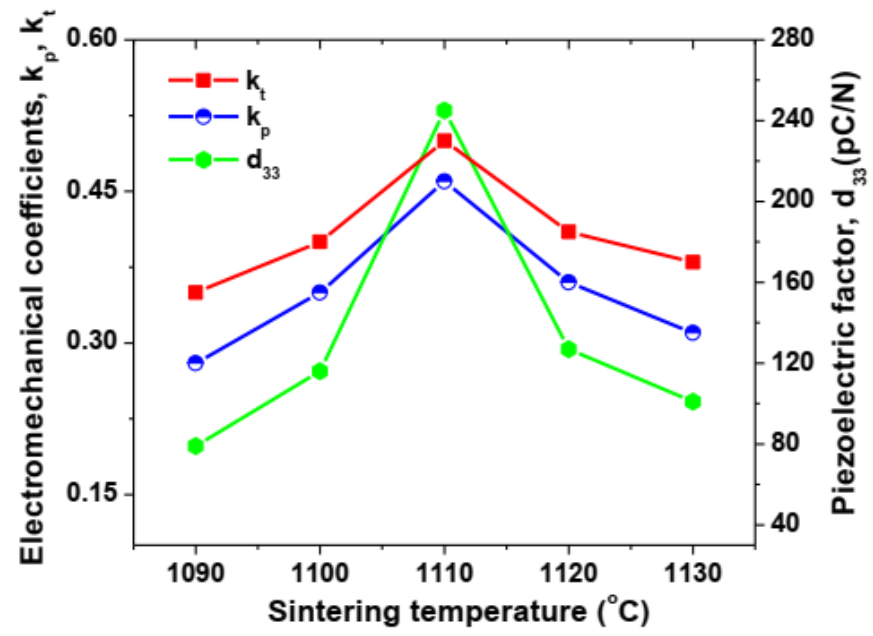

Figure 4. The $d_{33}, k_{p}$, and $k_{t}$ values for KNLNS-0.04BNKZ ceramics as a function of sintering temperature

Figure 4 shows the sintering temperature dependence of the electromechanical coupling coefficients, $k_{p}$ and $k_{t}$, and the $d_{33}$ piezoelectric factor of the KNLNS-0.04BNKZ ceramics. As shown in Figure 4, when the $T_{S}$ temperature increased from $1090{ }^{\circ} \mathrm{C}$ to $1110^{\circ} \mathrm{C}$, the $d_{33}, k_{p}$, and $k_{t}$ values of the ceramics increased sharply, reaching maximum values of $245 \mathrm{pC} / \mathrm{N}, 0.46$, and 0.50 , respectively, at $T_{S}=1110{ }^{\circ} \mathrm{C}$, and then decreased with further increases of $T_{S}$. Thus, it can be summarized that the optimum piezoelectric properties of the KNLNS-0.04BNKZ ceramics were obtained at $T_{S}=1110{ }^{\circ} \mathrm{C}$, indicating that by using the conventional sintering technique with an appropriate sintering temperature, the piezoelectric properties of the ceramics can be significantly improved. This improvement can be related to the high ceramic density and the coexistence of the 
two rhombohedral-tetragonal (R-T) ferroelectric phases at $T_{S}=1110{ }^{\circ} \mathrm{C}$. According to previous work (Liu et al., 2016; Tan et al., 2018; Xu, 1991), ceramics will achieve the best piezoelectric properties near this phase boundary due to the enhancement of the two ferroelectric phases.

\section{CONCLUSIONS}

Samples of $\quad 0.96\left(\mathrm{~K}_{0.48} \mathrm{Na}_{0.48} \mathrm{Li}_{0.04}\right)\left(\mathrm{Nb}_{0.95} \mathrm{Sb}_{0.05}\right) \mathrm{O}_{3}-0.04 \mathrm{Bi}_{0.5}\left(\mathrm{Na}_{0.82} \mathrm{~K}_{0.18}\right)_{0.5} \mathrm{ZrO}_{3}$ lead-free piezoceramic were successfully fabricated by the conventional sintering method at $T_{S}$ temperatures of $1090{ }^{\circ} \mathrm{C}, 1100{ }^{\circ} \mathrm{C}, 1110^{\circ} \mathrm{C}, 1120{ }^{\circ} \mathrm{C}$, and $1130{ }^{\circ} \mathrm{C}$ for 2 hours. The ceramic density increased with sintering temperature, reaching a maximum value of $4.22 \mathrm{~g} / \mathrm{cm}^{3}$ with dense microstructure at the sintering temperature of $1110{ }^{\circ} \mathrm{C}$. The experimental results show that the ceramic samples sintered at different temperatures all have a pure perovskite phase. The phase structure of the ceramics changed when the sintering temperature increased. At the sintering temperature of $1110{ }^{\circ} \mathrm{C}$, the ceramic phase structure was a mixture of two tetragonal and rhombohedral (R-T) ferroelectric phases. Due to the reinforcement of the R-T ferroelectric phases, this ceramic sample has the best piezoelectric properties, with electromechanical coupling coefficients $\mathrm{k}_{\mathrm{p}}$ of 0.46 and $\mathrm{k}_{\mathrm{t}}$ of 0.50 and a piezoelectric factor $\mathrm{d}_{33}$ of $245 \mathrm{pC} / \mathrm{N}$. Thus, the optimum sintering temperature of the KNLNS-0.04BNKZ ceramics fabricated by the conventional ceramic method is $1110^{\circ} \mathrm{C}$.

\section{ACKNOWLEDGMENTS}

This research is funded by Vietnam National Foundation for Science and Technology Development (NAFOSTED) under grant number 103.02-2019.08.

\section{REFERENCES}

Cheng, H., Zhou, W., Du, H., Luo, F. Zhu, D., \& Xu, B. (2014). Effect of sintering temperature on phase structure, microstructure, and electrical properties of $\left(\mathrm{K}_{0.5} \mathrm{Na}_{0.5}\right) \mathrm{NbO}_{3}-\left(\mathrm{Ba}_{0.6} \mathrm{Sr}_{0.4}\right)_{0.7} \mathrm{Bi}_{0.3} \mathrm{TiO}_{3}$ lead-free ceramics. Journal of Materials Science, 49, 1824-1831.

European Union. (2003). Directive 2002/96/EC of the European parliament and of the council of 27 January 2003 on waste electrical and electronic equipment (WEEE). Official Journal of the European Union, 46(L37), 24-39.

Gao, J., Hu, X., Zhang, L., Li, F., Zhang, L., Wang, Y., Hao, Y., Zhong, L., \& Ren, X. (2014). Major contributor to the large piezoelectric response in (1$\mathrm{x}) \mathrm{Ba}\left(\mathrm{Zr}_{0.2} \mathrm{Ti}_{0.8}\right) \mathrm{O}_{3}-\mathrm{x}\left(\mathrm{Ba}_{0.7} \mathrm{Ca}_{0.3}\right) \mathrm{TiO}_{3}$ ceramics: Domain wall motion. Applied Physics Letters, 104(25), 252909.

Guo, Y., Kakimoto, K., \& Ohsato, H. (2004). Phase transitional behavior and piezoelectric properties of $\left(\mathrm{Na}_{0.5} \mathrm{~K}_{0.5}\right) \mathrm{NbO}_{3}-\mathrm{LiNbO}_{3}$ ceramics. Appl. Phys. Lett. $85,4121$.

Haertling, G. H. (1999). Ferroelectric ceramics: History and technology. Journal of the American Ceramic Society, 82(4), 797-818. 
Huang, T., Xiao, D. -Q., Liang, W. -F., Wu, J. -G., Wang, Z., \& Zhu, J. -G. (2014). Sintering behavior of KNN-BNKT lead free piezoelectric ceramics. Ferroelectrics, 458, 37-42.

Jaffe, H. J., Berlincourt, D., Kinsley, T., Lambert, T. M., \& Schwartz, D. (1961). IRE standards on piezoelectric crystals: Measurements of piezoelectric ceramics, 1961. Proceedings of the Institute of Radio Engineers, 49(7), 1161-1169.

Liang, W., Xiao, D., Wu, W., Li, X., Sun, Y., \& Zhu, J. (2011). Effect of sintering temperature on phase transitions, properties and temperature stability of $\left(\mathrm{K}_{0.465} \mathrm{Na}_{0.465} \mathrm{Li}_{0.07}\right)\left(\mathrm{Nb}_{0.95} \mathrm{Sb}_{0.05}\right) \mathrm{O}_{3}$ lead free piezoelectric ceramics. Current Applied Physics, 11(3), S138-S142.

Liu, B., Zhang, Y., Li, P., Shen, B., \& Zhai, J. (2016). Phase transition and electrical properties of $\mathrm{Bi}_{0.5}\left(\mathrm{Na}_{0.8} \mathrm{~K}_{0.2}\right)_{0.5} \mathrm{ZrO}_{3}$ modified $\left(\mathrm{K}_{0.52} \mathrm{Na}_{0.48}\right)\left(\mathrm{Nb}_{0.95} \mathrm{Sb}_{0.05}\right) \mathrm{O}_{3}$ leadfree piezoelectric ceramics. Ceramics International, 42(12), 13824-13829.

Palei, P. K. \& Kumar, P. (2012). Role of sintering temperature on the phase stability and electrical properties of $0.94\left(\mathrm{~K}_{0.5} \mathrm{Na}_{0.5} \mathrm{NbO}_{3}\right)-0.06\left(\mathrm{LiSbO}_{3}\right)$ ceramics. Japanese Journal of Applied Physics, 51(1), 011503.

Phan, D. G., Huynh, Q. V., \& Le, D. V. (2018). Low-temperature sintering of $0.96\left(\mathrm{~K}_{0.5} \mathrm{Na}_{0.5}\right) \mathrm{NbO}_{3}-0.04 \mathrm{LiNbO}_{3}$ lead-free piezoelectric ceramics modified with CuO. International Journal of Materials Reseach, 109(11), 1071-1076.

Phan, D. G., Le, D. V., Le, T. U. T. (2021). Enhanced piezoelectric and energy storage performance of $0.96\left(\mathrm{~K}_{0.48} \mathrm{Na}_{0.48} \mathrm{Li}_{0.04}\right)\left(\mathrm{Nb}_{0.95} \mathrm{Sb}_{0.05}\right) \mathrm{O}_{3}-0.04 \mathrm{Bi}_{0.5}\left(\mathrm{Na}_{0.82} \mathrm{~K}_{0.18}\right)_{0.5} \mathrm{ZrO}_{3}$ ceramics using two-step sintering method. Journal of Materials Science: Materials in Electronics, 32(8), 13738-13747.

Phan, D. G., \& Nguyen, D. P. (2015). Effects of LiF on the structure and electrical properties of $\left(\mathrm{Na}_{0.52} \mathrm{~K}_{0.435} \mathrm{Li}_{0.045}\right) \mathrm{Nb}_{0.87} \mathrm{Sb}_{0.08} \mathrm{Ta}_{0.05} \mathrm{O}_{3}$ lead-free piezoelectric ceramics sintered at low temperatures. Journal of Materials Science and Chemical Engineering, 3(11), 13-20.

Qin, Y., Zhang, J. L., Yao, W., Lu, C., \& Zhang, S. (2016). Domain configuration and thermal stability of $\left(\mathrm{K}_{0.48} \mathrm{Na} 0.52\right)\left(\mathrm{Nb}_{0.96} \mathrm{Sb}_{0.04}\right) \mathrm{O}_{3}-\mathrm{Bi}_{0.5}\left(\mathrm{Na}_{0.82} \mathrm{~K}_{0.18}\right)_{0.5} \mathrm{ZrO}_{3}$ piezoceramics with high $\mathrm{d}_{33}$ coefficient. ACS Applied Materials \& Interfaces, $8(11), 7257-7265$.

Rubio-Marcos, F., López-Juárez, R., Rojas-Hernandez, R. E., Del Campo, A., RazoPérez, N., \& Fernandez, J. F. (2015). Lead-free piezoceramics: Revealing the role of the rhombohedral-tetragonal phase coexistence in enhancement of the piezoelectric properties. ACS Applied Materials \& Interfaces 7, 41, 23080-23088.

Saito, Y., Takao, H., Tani, T., Nonoyama, T., Takatori, K., Homma, T., Nagaya, T., \& Nakamura, M. (2004). Lead-free piezoceramics. Nature, 432(7013), 84-87.

Su, H. -H., Hong, C. -S., Chen, H. -R., Juang, Y. -D., Tsai, C. -C, \& Chu, S. -Y. (2018). Phase structure transformations and electrical properties of $\left(\mathrm{Na}_{0.52} \mathrm{~K}_{0.4425}\right)\left(\mathrm{Nb}_{0.8925} \mathrm{Sb}_{0.07}\right) \mathrm{O}_{3}-0.0375 \mathrm{LiTaO}_{3}$ ceramics according to sintering temperature. ECS Journal of Solid State Science and Technology, 7(3), N29-N35. 
Tan, Z., Xing, J., Wu, J., Chen, Q., Zhang, W., Zhu, J., \& Xiao, D. (2018). Sintering behavior, phase structure and electric properties of KNNTSBKNZ ceramics with excessive alkali metals. Journal of Materials Science: Materials in Electronics, 29, 5337-5348.

Tangsritrakul, J., \& Hall, D. A. (2018). Structural and functional characterisation of KNNS-BNKZ lead-free piezoceramics. Advances in Applied Ceramics, 117(1), 42-48.

Tangsritrakul, J., Tang, C. C., Day, S. J., \& Hall, D. A. (2020). Thermally-induced phase transformations in KNNS-BNKZ lead-free piezoceramics. Journal of the European Ceramic Society, 40(3), 672-681.

Wang, X., Wu, J., Xiao, D., Zhu, J., Cheng, X., Zheng, T., Zhang, B., Lou, X. \& Wang, X. (2014). Giant piezoelectricity in potassium-sodium niobate lead-free ceramics. Journal of the American Chemical Society, 136(7), 2905-2910.

Wu, J., Wang, X., Cheng, X., Zheng, T., Zhang, B., Xiao, D., Zhu, J., \& Lou, X. (2014). New potassium-sodium niobate lead-free piezoceramic: Giant-d33 vs. sintering temperature. Journal of Applied Physics, 115(11), 114104.

Xing, J., Zheng, T., Wu, J., Xiao, D., \& Zhu, J. (2018). Progress on the doping and phase boundary design of potassium-sodium niobate lead-free ceramics. Journal of Advanced Dielectrics, 8(3), 1830003.

$\mathrm{Xu}, \mathrm{Y}$. (1991). Ferroelectric materials and their applications. Elsevier Science.

Yao, F. -Z., Patterson, E. A., Wang, K., Jo, W., Rödel, J., \& Li, J. -F. (2014). Enhanced bipolar fatigue resistance in $\mathrm{CaZrO}_{3}$-modified $(\mathrm{K}, \mathrm{Na}) \mathrm{NbO}_{3}$ lead-free piezoceramics. Applied Physics Letters, 104(24), 242912.

Zhai, Y., Du, J., Chen, C., Hao, J., Fu, P., Li, W., \& Xu, Z. (2019). Temperature stability and electrical properties of $\mathrm{Tm}_{2} \mathrm{O}_{3}$ doped KNN-based ceramics. Journal of Materials Science: Materials in Electronics, 30(5), 4716-4725.

Zhang, N., Zheng, T., \& Wu, J. (2020). Lead-free (K,Na) $\mathrm{NbO}_{3}$-based materials: Preparation techniques and piezoelectricity. ACS Omega, 5(7), 3099-3107. 